\title{
Multifuncionalidade no espaço rural brasileiro: o turismo na região vinícola do Vale do São Francisco
}

\section{Multifunctionality in rural Brazilian: the tourism in wine region of the São Francisco Valley}

\author{
Patrícia Lins de Arroxelas Galvão, Cleber Augusto Trindade Castro, \\ Priscilla Carla Leite Marques
}

RESUMO: Este trabalho realizou uma análise sobre a prática do turismo no semiárido nordestino, mais precisamente na região vinícola localizada nos estados de Pernambuco e Bahia. O que preexistiu por décadas foi uma apropriação do espaço pela agricultura de subsistência. A partir da prática da agricultura moderna e de atividades não agrícolas, o meio rural brasileiro tem sofrido transformações, envolvendo atividades do setor de serviços, inclusive o turismo, que oferece possibilidades de melhoria de vida, ao oferecer renda complementar às atividades primárias como agricultura, pecuária e extrativismo. Esses serviços instalam-se no meio rural, estabelecendo novas relações, tornando-o diferenciado. Objetivou-se analisar as dinâmicas do turismo no Vale do São Francisco, observando novas práticas, fluxos e ocupação do espaço rural, com implantação de novas estruturas turísticas. A pesquisa possui abordagem qualitativa e foi realizada por meio de levantamento e análise bibliográfica, além do trabalho de campo desenvolvido pela técnica da observação participante junto aos empresários, agentes de governos e instituições ligadas à vinicultura e ao turismo. $\mathrm{O}$ Vale desenvolve agricultura irrigada para mercados nacionais e internacionais, possui característica climática peculiar, pois necessita de irrigação devido ao baixo índice pluviométrico. Assim, torna-se possível programar colheitas e obter 2,5 safras ao ano. Impulsionada pelos projetos de agronegócio, a região atrai investimentos de vinícolas internacionais, gerando euforia pouco comum em cidades do sertão, normalmente marcadas pela seca e baixo índice de desenvolvimento humano. Apostando na produção de vinhos, poder público e empresários voltam-se para estruturação do enoturismo. Destacam-se cinco vinícolas que, aliadas à tecnologia, possuem vinhos premiados internacionalmente. Com visitas agendadas, turistas podem conhecer sistema de produção e fazer degustações. O turismo valorizou o espaço local, contudo ainda se apresenta de forma singular em vias de consolidação. Reveste-se de forte refinamento, recriando o espaço a partir de ações cada vez mais artificiais para realizar desejos dos visitantes. Embora grandes proprietários estejam se unindo em torno da atividade e se beneficiando mais diretamente das políticas de fomento, esta não é a realidade vivenciada pelos pequenos produtores, empregados e artesãos locais. Portanto, o mundo rural possui um expressivo dinamismo e é, cada vez mais, heterogêneo. Deve ser compreendido como elo essencial entre o rural e a dinâmica urbana, integrando o meio rural ao conjunto da sociedade com objetivo de assegurar os contatos sociais. Essa multifuncionalidade e diversificação do meio rural constituem uma nova forma de organização dessas atividades agrícolas aliadas à prática do turismo.

PALAVRAS-CHAVE: Multifuncionalidade; Espaço Rural; Turismo; Vinícola. 


\section{ABSTRACT}

This paper conducted an analysis of the practice of tourism in the northeast semiarid, specifically in the wine region in the states of Pernambuco and Bahia. For decades there was an appropriation of space for subsistence agriculture. Through the practice of modern agriculture and/or non-agricultural activities, the rural areas in Brazil have undergone transformations, including services like tourism that enables an improvement in life conditions when providing complementary income to the primary activities such as agriculture, livestock and extractivism. These services emerge in rural areas, establishing relations, changing its characteristics. São Francisco Valley develops irrigated agriculture seeking the aiming the national and international market, it has a peculiar climate since it needs to be irrigated due to the low rainfall. This way, it is possible to schedule and obtain 2,5 harvests a year. Stimulated by the agribusiness projects, the regions attract investments from international wineries, changing the dynamic of hinterland cities usually characterized by drought and low human development index. Relying on wine production, the government and businessmen focus on the organization of wine tourism. The aim is to analyze the tourist dynamic in the São Francisco Valley, studying new practices, flows and occupation in rural areas with the implementation of new tourist facilities. The research has a qualitative approached and was conducted through bibliographical analysis and field research developed by the participant observation technique with entrepreneurs, government and institutions related to wineries and tourism. Due to the tourism, the space has been recreated to fulfill the visitors' needs and expectation, however it is still in the process of consolidation. Although the landowners are involved in the activity and getting benefits directly from development policies, these benefits are not experienced by the small producers, employees and local artisans. Therefore, the rural areas have an expressive dynamism and it is increasingly heterogeneous. This multifunctionality and diversification of rural areas constitute a new form of organization of these agricultural activities together with tourism.

KEYWORDS: Multifunctionality; Rural Space; Tourism; Winery.

\section{Introdução}

O meio rural brasileiro vem assumindo novas funções além de sua função essencialmente agrícola, uma vez que está representando, também, o local de moradia, de lazer, de prestação de serviços e de emprego para pessoas ocupadas em atividades não agrícolas. Ou seja, os residentes na zona rural não estão somente ocupados em atividades agropecuárias, mas sim, vem buscando alternativas para elevar seus níveis de bem-estar e qualidade de vida.

O processo de transformação socioeconômico do meio rural se deve, principalmente, pela estagnação da produção agrícola e pela lenta desarticulação do tradicional sistema produtivo. A pluriatividade surge nesse contexto, em virtude da industrialização difusa de diversos setores. Assim, a expansão do setor industrial e o decorrente aumento na demanda por mão de obra proporcionaram o estabelecimento de diversas atividades econômicas como os serviços, os empregos autônomos e as funções políticas.

Nas décadas de 80 e 90, houve uma considerável diminuição das distâncias geográficas e a consequente aceleração das relações de mercado, 
juntamente com o surgimento e crescimento da tecnologia de informação e comunicação. Sendo assim, percebem-se as transformações nas características do modo de vida rural. Carneiro (1999) enfatiza que a modernização da agricultura foi moldada no padrão urbano-industrial, pois seus efeitos sobre a população local e a reação a tais processos não são uniformes, assim como essas medidas não atingem com a mesma intensidade e proporções as diferentes categorias de produtores. Assim, a modernização não homogeneíza o rural, ao contrário, integra-o às facilidades do urbano. Desse modo, o meio rural deixa de ser um espaço precário e passa a ser um lugar agradável, oferecendo conforto e maior atratividade.

Dentro dessa perspectiva, Wanderley (2002, p.40) afirma que o mundo rural está socialmente integrado à sociedade e ao contexto das relações internacionais, deixando de ser um universo isolado, como antes era visto. É importante salientar que o rural "mantém peculiaridades históricas, sociais, culturais e ecológicas que o identificam como uma realidade própria, da qual fazem parte as próprias formas de inserção na sociedade". Cada vez mais as transformações vivenciadas no meio agrário vêm estabelecendo "novas relações e significados sociais", segundo Almeida, Froehlich e Riedl (2000, p.85). O rural não mais pode ser visto como sinônimo de atraso, uma vez que as ocupações essencialmente agrícolas vêm sofrendo mudanças que, embora ainda limitadas geograficamente, tendem à expansão. Isto significa que são estimuladas as atividades não agrícolas e, consequentemente, a geração de rendas complementares às tradicionais funções destas propriedades. Ou seja, no mundo agrário uma nova dinâmica vem se firmando, desta vez, pelo uso turístico do território, que gera novos fluxos, novas demandas.

$\mathrm{Na}$ área objeto desta pesquisa, a região vinícola do Vale do São Francisco, o que existiu por décadas foi a apropriação do espaço pela agricultura de subsistência. A área também está inserida no contexto de grandes transformações no espaço, antes marcada pela prática da agricultura voltada para abastecimento local, atualmente, desenvolve a agricultura irrigada, tendo como principais produtos: a manga, o coco, a goiaba, o tomate e a uva, inclusive para exportação, como a uva apirênica (sem sementes). Devido à irrigação, torna-se possível programar toda a produção. Atualmente vem se consolidando como uma das regiões mais promissoras do país, detém $15 \%$ do mercado nacional de vinhos finos e se destaca como modelo de desenvolvimento para o Nordeste, como ressalta Vinhovasf (2011).

Devido a investimentos em tecnologias para irrigação periódica, a vitivinicultura no vale é desenvolvida sob características climáticas que a distingue das demais localidades tradicionalmente vitícolas. Através da irrigação, é possível programar colheitas para todas as semanas do ano e vinificações periódicas conforme a produção e a tancagem disponível. O local de estudo contempla os municípios de Lagoa Grande, Santa Maria da Boa Vista e Petrolina, localizados no semiárido de Pernambuco, e Casa Nova, na Bahia.

Diante desse contexto que se apresenta, tem-se como objetivo desta investigação analisar as novas configurações espaciais e sociais da região 
vinícola do Vale do São Francisco, observando novas práticas culturais, sociais e econômicas relativas às diversas atividades existentes na localidade, ressaltando a multifuncionalidade, além de identificar os atores sociais envolvidos, buscando entender a atuação desses diversos atores na nova dinâmica existente no meio rural nordestino.

Para a efetiva contribuição desta pesquisa, foi trabalhada uma abordagem qualitativa, realizada por meio de levantamento e análise documental e bibliográfica que forneceram subsídios teóricos e reflexões sobre a efetiva transformação do turismo, além de realização de trabalho de campo, desenvolvido pela técnica da observação participante, junto aos empresários vinculados ao turismo e ao agronegócio, pequenos produtores rurais, setor público das três esferas (municipal, estadual e federal), comunidade local e instituições ligadas à vinicultura e turismo. Como também, observação da prática da atividade turística e lazer nas vinícolas.

Nesse cenário, o turismo vem se consolidando como um dos fenômenos de grande relevância econômica para a localidade. Além disso, gera transformações ambientais e socioculturais. Desse modo, o enoturismo desenvolve a região através da integração produtiva da uva e do vinho, das famílias e organizações envolvidas nessas atividades e dos visitantes. $\mathrm{Na}$ realidade, o semiárido nordestino, por muito tempo, teve sua imagem comprometida como uma região problema. Atualmente, após políticas de modernização, industrialização e alternativas pautadas nas potencialidades naturais, o agronegócio surgiu como promissor e o Nordeste passa a ser visto como possuidor de um meio geográfico associado a atividades mais modernas e também de serviços.

\section{Nova Ruralidade: diversificação do meio rural}

Pesquisas recentes realizadas no Brasil vêm mostrando a dinâmica nos espaços rurais que estão fomentando discussões atuais sobre as novas ruralidades: a apropriação do espaço rural por atividades não agrícolas associadas à revalorização do meio rural como espaço de lazer ou residência; a identificação do meio agrário como lugar de trabalho e vida, por meio do crescimento e valorização da agricultura familiar como ator social no processo de desenvolvimento econômico. Como afirma Carneiro (2002), nova dinâmica relativa às atividades associadas ao lazer vislumbra para a questão do mundo rural não estar mais definido, exclusivamente, como espaço agrícola ou ligado intrinsicamente às atividades agrícolas.

A agricultura tradicional, embora ainda seja a principal atividade do meio rural, está dividindo sua atenção com novas funções que despontam na área rural. Ou melhor, o espaço rural está se diversificando, tornando-se heterogêneo e dinamizando a economia local, por meio de novos nichos de mercado. Além da expansão dessas novas atividades, há o crescimento de atividades não-agrícolas, inclusive na área de serviços. O meio rural torna-se, então, um espaço diferenciado, oferecendo novas formas de lazer, bem como padrões de qualidades e conforto a seus visitantes. 


\section{Pluriatividade: um outro entendimento para o rural}

Estudos feitos por Graziano da Silva (1998; 2005), Carneiro (1999; 2002), Wanderley (2002) e o Projeto Rurbano - UNICAMP (2000) demonstram a expansão das atividades não agrícolas, ligadas sobretudo ao setor de comércio, indústria e serviços. Essa nova característica aponta para uma tendência à pluriatividade, prática que pode revelar estratégia de reprodução social de famílias sem condições de se manter exclusivamente da atividade agrícola, como também pode indicar mudança no padrão de exploração agrícola. Assim, associadas às atividades do setor de serviços, a pluriatividade, combinada com a noção de multifuncionalidade, tende a incentivar a discussão sobre as características das novas ruralidades na sociedade.

Então, carece de entendimento para a discussão e definição do termo "rural", pois, antes, era tido como local de atraso, oposto ao urbano, carente de serviços públicos e sociais. Carneiro (2002, p. 225) reflete sobre a pouca possibilidade de haver lugar para se pensar o rural como espaço desenvolvido, uma vez que ele logo se transformaria em "urbano". Para a autora, "a categoria 'rural' revela-se, assim, inútil". Kageyama (2008) também aborda o rural de forma distinta das visões mais antigas e ressalta que esta categoria passa a ser uma representação social, produzida por diferentes grupos.

O rural passa a ser entendido como suporte para as relações sociais e passa, ele mesmo, a ser construído socialmente como forma de diferenciação. Surge, então, nova dinâmica social, econômica e cultural locais, oriundas das relações rural / urbano, que são materializadas na produção de novos serviços e bens de consumo (econômicos e culturais), resultando no deslocamento humano e novos reconhecimentos. Sendo assim, o turismo no meio rural, as residências rurais, os eventos sociais e os espaços de lazer e entretenimento refletem em representações evidentes dessa nova dinâmica e produção do espaço. Essas novas atividades reforçam o esforço da reprodução das famílias e as possibilidades de permanência no meio rural.

Carneiro (2002) indica dois fatores que contribuem para essa nova dinâmica rural: maior mobilidade provocada pelos meios de comunicação real (transporte, estradas, malha aérea) e virtuais (internet, telefonia, TV, rádio), causando o estreitamento das relações culturais e sociais distintas; campo como área de lazer e residência, com a busca pela qualidade de vida, bem estar, valorização da natureza e patrimônio cultural, fomentando o turismo mudanças no padrão de consumo e hábitos e práticas de vida nas localidades. Consequentemente, ampliam-se e diversificam-se o mercado de trabalho nas regiões com vocação turística, criando novas necessidades para a população, nova organização social e econômica das unidades familiares.

Complementarmente, Graziano da Silva e Del Grossi (2005) abordam a complexidade do mundo rural e indicam quatro conjuntos que formatam essa nova dinâmica: modernização da agricultura, vinculada estreitamente à agroindústria, formando complexos agroindustriais; unidades de subsistência bastante rudimentares; atividades não agrícolas, ligadas ao lazer, moradia, 
indústrias e prestação de serviços; atividades agropecuárias mais intensas, voltadas a um mercado mais sofisticado e seletivo.

As atividades não agrícolas têm crescido substancialmente, demonstrando que a pluriatividade pode ser estratégia de sobrevivência das famílias, mesmo se parte desta oferta de trabalho seja obtida de forma precária e baixa qualificação. Assim, entendendo o espaço rural caracterizado como diferenciado, é resultado da ocupação do território, da estrutura de posse e uso da terra, da conservação das paisagens naturais e construídas e da relação campo-cidade.

Outra característica é o espaço rural enquanto lugar de vida, um espaço identitário. Como já mencionado, o rural precisa da integração com a cidade, seja para escoamento da produção, mercado consumidor, como para obter tecnologia, assistência técnica e desenvolvimento de pesquisas agropecuárias, resultando na configuração de uma rede de relações recíprocas. Portanto, o mundo rural não pode mais ser associado a espaços atrasados, pois ele possui um expressivo dinamismo, é heterogêneo. Do mesmo modo, o desenvolvimento do meio rural não deve ser entendido como superação do rural.

O "novo rural" tem implicado na criação de novos produtos e serviços, associados a novos mercados. Graziano da Silva (1997), ao analisar a importância das rendas não agrícolas para o meio rural brasileiro, ressalta que não se pode mais caracterizar o rural somente como agrário. Visto que há um conjunto de atividades, como prestação de serviços, comércio e indústria que respondem cada vez mais pela ocupação dos trabalhadores do meio rural. Para o autor, a diversidade de atividades no espaço rural pode representar uma estratégia de sobrevivência da família, como também uma estratégia de expansão do capital. Com base nisso, a análise dessa diversificação deve contemplar não apenas a unidade produtiva, mas também todo o contexto nos quais essas atividades estão inseridas. Pois, considerase que a ocorrência da pluriatividade é uma das respostas que as famílias procuram dar às mudanças das circunstâncias, tanto econômicas quanto sociais.

Deve-se entender quais e como se dão essas "novas" formas de ocupação que passaram a proliferar no espaço rural. Entre elas são destacadas: conjunto de profissões tidas como urbanas (trabalhadores domésticos, mecânicos, secretárias, entre outras); moradias de segunda residência; atividades de conservação; áreas de lazer e atividades turísticas (hotéis fazenda, fazenda hotéis, pesque pague, passeios, trilhas, entre outras). Percebe-se que essas novas atividades demandaram um número crescente de pessoas para dar sustentação à expansão das atividades turísticas no espaço rural, o que possibilitou que os membros das famílias, liberados das atividades rotineiras da atividade agrícola, pudessem ocupar as vagas geradas na expansão do turismo rural, por exemplo.

Importante, também, destacar o significado do termo pluriatividade o contexto do meio rural. Trata-se de um fenômeno que implica na combinação de duas ou mais atividades, sendo uma delas a agricultura. Assim, pode-se, então, ser classificada de acordo com as atividades secundárias exploradas 
pelo agricultor: pluriatividade de base agrícola (se forem atividades relacionadas ao setor agrícola, por exemplo, emprego de mão de obra em propriedades vizinhas em períodos de maior demanda) ou intersetorial (relacionado a atividades de outros setores, como a venda de derivados dos produtos produzidos no local, como doces, vinhos ou a prestação de serviços, como é o caso do turismo rural, condução e recepção de grupos).

Assim, as propriedades de agricultura familiar entram como núcleos desse desenvolvimento, uma vez que as famílias essencialmente agrícolas são aquelas em que a força de trabalho familiar é empregada somente nas atividades agropecuárias. Já as famílias com caráter pluriativo, seu significado aponta que um ou mais membros da família exercem uma atividade extra agrícola. Essa atividade extra referida pode ser o turismo no espaço rural como uma possibilidade de pluriatividade. O turismo rural como nova fonte de renda gera mudanças que formam uma rede de desenvolvimento, oferecendo novas oportunidades para a região.

\section{Multifuncionalidade: uma nova dinâmica do turismo no campo}

A discussão sobre multifuncionalidade da agricultura acaba por responder à necessidade de se entender a agricultura familiar no novo contexto que lhe é proposto, por meio da interação cada vez mais presente entre valores e práticas sociais, culturais e econômicas diversificadas. Nesse sentido, a reprodução social passa a ser definida, também, pela satisfação econômica e pelas demandas culturais e sociais. Percebe-se o agricultor também como um ser social de múltiplas inserções e valores culturais.

Contudo, a noção de multifuncionalidade possui visão integradora da agricultura com projetos que geram, inclusive, desenvolvimento local, respeitando a diversidade e peculiaridade das realidades locais. Bonnal e Maluf (2007) relacionam a multifuncionalidade ao processo de desenvolvimento, ressaltando elementos relacionados ao desenvolvimento social e cultural da localidade, além de seu reflexo no meio rural, buscando (re)definir o que os pesquisadores vêm discutindo sobre multifuncionalidade da agricultura.

Cabe ressaltar que a inserção da população rural no mercado de trabalho, de bens materiais e imateriais, das trocas simbólicas entre "urbano" e o "rural" tornam complicado de se definir a ruralidade. É necessário mudar o olhar sobre o rural e buscar definir a ruralidade dentro do contexto da multifuncionalidade, pois, como constata Carneiro (2002), o campo não se submete a um processo de homogeneização, é preciso observar as diferentes formas de expressão da ruralidade, os contextos espaciais, culturais e sociais, que são peculiares e heterogêneos. Assim, entende-se que a ruralidade é um processo dinâmico e em constante reestruturação dos elementos locais, a partir da implementação de novos valores, hábitos e técnicas.

As atividades no campo agropecuário dispõem de diversas informações como: produção, áreas de cultivo, comércio e emprego, que facilitam a construção de uma dinâmica do fluxo comercial, pois estes estão identificados em territórios que transpõem as delimitações do espaço, pois, 
conforme Haesbaert (2004), território não é um simples espaço físico, mas uma representação simbólica, subjetiva, construída socialmente com as referências culturais dos que lá vivem. Territorialidades são formas de poder por apropriações espaciais e também de resistências em territórios nacionais. Refere-se às práticas materiais e simbólicas que garantem a permanência de um determinado território por um agente social, que poderia ser 0 representante do Estado, os grupos sociais e as empresas, conforme indica Corrêa (2003). Bonnal e Maluf (2007) ressaltam a relevância das discussões sobre território uma vez que veio a contribuir como um direcionador das políticas, particularmente ligadas ao rural.

O processo de transformação socioeconômico no meio rural se deve, principalmente, pela estagnação da produção agrícola e pela lenta desarticulação do tradicional sistema produtivo. Assim, a expansão do setor industrial e o decorrente aumento na demanda por mão de obra proporcionaram o estabelecimento de diversas atividades econômicas como os serviços, os empregos autônomos e as funções políticas. Nas décadas de 1980 e 1990, houve uma considerável diminuição das distâncias geográficas e a consequente aceleração das relações de mercado, juntamente com o surgimento e crescimento da tecnologia de informação e comunicação.

Assim, percebe-se as transformações nas características do modo de vida rural. Para Wanderley (2002), o "rural" é um modo particular de vida social. Contribui para a troca de conhecimentos técnico e científico, levando para o campo todo aparato tecnológico. Carneiro (1999) enfatiza a modernização da agricultura e afirma que esta não homogeneíza o rural, ao contrário, integra-o às facilidades do urbano. O meio rural deixa de ser precário e passa a ser um lugar agradável, oferecendo conforto.

É necessário entender que o deslocamento de pessoas transforma o espaço, não somente do ponto de vista econômico, como também da abordagem física, visto que o espaço requer equipamentos de consumo coletivo e uma infinidade de facilidades e atrações naturais, histórico-culturais e, inclusive, produtos artificiais, dinamizando a atividade turística. Fonseca (2005, p. 34-35) ressalta que o espaço é diferenciado, mas essa diversidade territorial é fundamental para os estudos do turismo. O espaço é, portanto, o local onde se realiza a vida social, ou seja, a "dinâmica social se materializa no espaço".

As famílias com caráter pluriativo tem seu significado a respeito de que um ou mais membros da família exercem uma atividade não agrícola. Essa atividade extra referida pode ser o turismo rural como uma alternativa de pluriatividade. O turismo no meio rural como nova fonte de renda gera mudanças que formam uma rede de desenvolvimento, oferecendo novas oportunidades para a região. A atividade turística que ocorre na unidade de produção dos agricultores familiares e as quais mantêm as atividades econômicas típicas da agricultura familiar, porém dispostos a valorizar, respeitar e compartilhar modos de vida, patrimônio cultural e natural, utilizando-se de oferta de produtos e serviços de qualidade, conforme Schneider e Fialho (2000). 
É importante destacar que a integração não deva ser meramente econômica, mas também cultural, para proporcionar bem estar aos envolvidos (turistas, agricultores). Assim, a possibilidade de uso do espaço rural pelo turismo poderá desencadear outras atividades e serviços, cuja contribuição pode agregar diversas atividades junto à propriedade rural. Essa diversificação do meio rural constitui uma nova forma de organização dessas novas atividades, conforme Carneiro (1999), e apresenta certos benefícios, tais como: preservação de uma demanda adequada aos serviços na área rural, evitando o êxodo rural; facilidade em obter rendas complementares; geração de formas de cooperação não competitiva entre as empresas; e ainda, oferece oportunidade para negociações a respeito da preservação ambiental.

Como já observado, o crescimento da oferta de alternativas de emprego, alimentada pelos capitais de origem urbana, provoca uma reavaliação do modelo de exploração agrícola, criando espaço para o exercício da pluriatividade. Dessa forma, o turismo aparece como uma fonte alternativa de emprego e renda, ampliando a oferta de empregos, principalmente com atividades ligadas à construção, ao comércio, ao lazer e entretenimento. Portanto, essas novas funções no rural impulsionam a inserção dos jovens no mercado de trabalho, o que favorecem a permanência destes jovens no meio rural, evitando sua saída do campo.

Para Graziano da Silva (1997), esse conjunto de atividades, como prestação de serviços, comércio e indústria respondem, cada vez mais, pela ocupação desses trabalhadores no meio rural. A diversidade de atividades no espaço rural pode representar uma estratégia de sobrevivência da família, como também pode contribuir para a expansão do capital. Com base nessa perspectiva, a análise dessa diversificação deve contemplar não apenas a unidade produtiva, mas também todo o contexto nos quais essas atividades estão inseridas. Pois, considera-se que a ocorrência das novas funções no meio agrícola é uma das respostas que as famílias procuram dar às mudanças das circunstâncias tanto econômicas quanto sociais.

No contexto geral, as preocupações espaciais com a difusão da função turística são provenientes das análises da distribuição dos equipamentos e da organização socioespacial. São também analisados aspectos como: a atração da paisagem, o clima, a infraestrutura e equipamentos turísticos e as relações sociais e produção cultural dos lugares visitados, entre outros fatores. Nesse sentido, de acordo com Barros (2002, p.12) a atividade turística se expande "usualmente por áreas onde existiam assentamentos humanos. Isto quer dizer que quando a difusão turística começa a acontecer em uma região, inicia-se uma interação entre os componentes da função nova e os componentes da região receptora". Tem-se, então, que o reflexo desta interação neste espaço agrário tem desencadeado um processo de redefinição das suas atividades econômicas, refletindo nas estruturas política e sociocultural.

\section{Enoturismo: definição e reflexões sobre o turismo no meio rural}


A dinâmica do Turismo se expressa nos espaços sociais e nos territórios, estimulando pesquisadores e estudiosos de diversos campos do saber. O deslocamento de grupos humanos entre diferentes lugares e culturas provoca a (re)construção de espaços, induzindo a mudanças no uso desse espaço. Portanto, estudar o Turismo exige analisar o espaço, que abrange toda a sociedade e suas interrelações. Pearce (2003, p. 13) afirma que a Geografia do Turismo se interessa pelas relações e fenômenos causados pelas viagens, delimitados em campos de estudos a ser considerados: os movimentos e fluxos turísticos, os modelos de desenvolvimento do espaço turístico, os padrões de distribuição espacial da oferta e da demanda e os impactos da atividade no meio.

De acordo com Barros (2002, p.12) o turismo se difunde, geralmente, por localidades onde já existem assentamentos humanos, ou seja, "quando a difusão turística começa a acontecer em uma região, inicia-se uma interação entre os componentes da função nova e os componentes da região receptora". Nesse sentido, o reflexo da interação neste espaço agrário tem desencadeado um processo de redefinição das suas atividades econômicas, refletindo nas estruturas política e sociocultural. Conforme Pearce (2003, p. 25), o turismo é essencialmente o elo entre pessoas e lugares, ou melhor, é o "conjunto de relações e fenômenos originados com as viagens e estadas temporárias de pessoas que estão viajando sobretudo a lazer ou com finalidades recreativas".

O turismo é concebido como forma de lazer, uma atividade que exige viagens, deslocamentos, infraestrutura urbana e turística: serviços personalizados, transportes e acomodações. Nessa perspectiva, o turismo está cada vez mais globalizado, dependente de redes aéreas, terrestres e marítimas e, sobretudo, das inovações tecnológicas para cumprir seu papel de aproximar pessoas a espaços sempre mais longínquos e desertos.

Baseado nessas afirmações, o turismo assume uma destacada função na atualidade, sendo considerado por Rodrigues (1996, p. 17-18) como

uma instituição, uma prática social, uma fonte pioneira, um processo civilizatório, um sistema de valores, um estilo de vida - um produtor, consumidor e organizador de espaços uma 'indústria', um comércio, uma rede imbricada e aprimorada de serviços.

O Enoturismo é uma atividade recente caracterizada pelo deslocamento de pessoas a localidades que possuem tradição na produção de uvas e fabricação de vinhos, também visitas às regiões emergentes da atualidade. Durante as visitações, outros produtos e serviços são oferecidos pela população, gerando mais oportunidade para a formatação do sistema turístico local. Conforme Locks (2005, p.159), o "Enoturismo se fundamenta em viagens que são motivadas por pessoas que apreciam o aroma, o sabor e a degustação de vinhos, bem como a apreciação das tradições e tipicidades das localidades produtoras". Já Splendor (2003, p.36) diz que é uma nova 
forma de excursionismo ${ }^{1}$, engloba toda a área onde a produção industrial e a de competitividade são oferecidas aos consumidores.

Trata-se de visitação às unidades produtivas, onde os turistas participam de visitas guiadas nas cantinas e realizam a degustação dos vinhos produzidos na localidade. Durante a visita, os turistas são guiados por itinerários propositadamente estudados, onde podem ser visitados museus, vinhedos, zonas produtivas.

Além disso, as vinícolas foram lançadas como produto turístico, algumas, inclusive, oferecem alimentação, hospedagem e serviços de lazer e entretenimento. O que Locks (2005, p. 160) assevera é a provisão de bens e serviços que atraem o turista e não está associado apenas às cantinas, mas também a "todos os negócios envolvidos com o vinho, com o turismo e com as indústrias associadas com a região vinícola. Isto inclui meios de hospedagem, guias, lojas de presentes".

Banks e Overton (2009) alertam para o fato de que se deve estar mais antenado com as mudanças nos padrões de consumo global de vinho e com a evolução da produção mundial, pois, cada vez mais, o mundo do vinho vai se tornar mais complexo, acomodando novas regiões e também diferentes formas de produção, artesanal tradicional e moderna, intimamente ligada ao lugar e cultura da videira.

Segundo Getz e Brown (2006, p. 147), a definição de Enoturismo não é um resultado uniforme, porque quando é analisado numa perspectiva de marketing, percebe-se que a atividade está relacionada à motivação e às experiências de viagem. Ressalta-se que o Enoturismo é

simultaneously a form of consumer behavior, a strategy by which destinations develop and market wine-related attractions and imagery, and a marketing opportunity for wineries to educate, and to sell their products, directly to consumers ${ }^{2}$.

Para Simões (2008), é importante destacar a oferta adequada de infraestrutura básica e turística, incluindo nesse contexto, a motivação principal da visita: apreciação do vinho e visita aos estabelecimentos vinculados à gastronomia local. Para Río Rama et al. (2014), a oferta enoturística deve oferecer maior nível de qualidade e adequada gestão em todos os empreendimentos que compõem a rota, para que este sistema seja capaz de gerar um real interesse turístico. Para que a prática do enoturismo se fortaleça na região, alguns incrementos são necessários, tais como a caracterização geográfica do vinho, tornando-se uma referência para assimilar a origem dos produtos (FALCADE, 1999, p.43). Trata-se de um fator de identidade, associado ao conceito de qualidade proveniente da uva e região produtora.

Portanto, percebe-se que a partir dessas análises toda a relação de envolvimento e comprometimento do enoturismo com os empreendimentos turísticos em geral. Embora trate de um tipo de turismo em que os elementos 
referentes ao processo de elaboração do vinho são o centro da experiência da viagem, faz-se necessário utilizar outros atrativos regionais como estratégias de vendas e de mercado para produtos locais, incrementando e contribuindo para aumentar a permanência do turista na localidade visitada.

Dentro dessa perspectiva, o universo vitivinícola vem obtendo progressos no parque industrial e a estrutura turística está em crescimento progressivo. Vale ressaltar que o enoturismo é o caminho de integração entre regiões, onde é possível aproveitar o produto base, a gastronomia local aliada ao vinho, promovendo uma atração conjugada. Representa um veículo para que os turistas visitem uma região, descobrindo através do vinho todos os aspectos ambientais e culturais de uma região.

Nessa ótica, os roteiros permitem aos visitantes vivenciarem o mundo rural, facilitando a dinâmica das compras de produtos regionais e contribuindo para o conhecimento da região e das empresas envolvidas. Salienta-se roteiros em cantinas, unidades produtivas, artesanato e recantos naturais. Portanto, os roteiros consolidam os pratos típicos, enfatizando a produção de vinhos cujo eixo temático é constituído pela uva. Como lembra Schlüter (2003, p. 73), essas rotas se valem da gastronomia como elemento de recuperação e valorização cultural.

\section{O turismo na região vinícola do semiárido nordestino}

O início da vitivinicultura na região do São Francisco data, aproximadamente, da década de 20 , época em que a uva de mesa era cultivada em forma de jardins. Na década de 60, a produção de vinhos foi implantada como atividade econômica, através da Comissão do Vale, hoje CODEVASF - Companhia de Desenvolvimento do Vale do São Francisco, no município de Santa Maria da Boa Vista - PE. A partir de então, o projeto piloto do Bebedouro começou a realizar experiências em áreas irrigadas. Assim, em 1984, um italiano adquiriu algumas propriedades agrícolas em Santa Maria da Boa Vista, onde instalou a Fazenda Milano. Com a chegada dos gaúchos, final da década de 1980, início da década de 1990, a produção de vinhos finos passou a ser feita em larga escala. A partir dos anos 2000, constata-se 0 início do fluxo de visitantes nas unidades vitivinícolas, seja por motivos comerciais, de caráter técnico-científico ou de lazer, dinamizando a economia local.

Dentro desse novo cenário, a produção de uva para vinho está atribuindo nova funcionalidade ao espaço: a visita técnica monitorada por enólogos para conhecer todo o processo de elaboração dos vinhos, a degustação e a venda dos produtos nas cantinas e ainda a oferta de meios de hospedagem e opções de entretenimento e lazer nas propriedades rurais. Tais atividades estão oferecendo novas atribuições econômicas, inerentes ao turismo globalizado, criando novo arranjo no espaço produzido, modificando totalmente a dinâmica local.

A região surge como pólo de expressão nacional na produção de frutas em geral, uma vez que houve grandes investimentos em tecnologias para irrigação periódica. A fruticultura irrigada produz frutas para exportação: são 
manga, coco verde, uva apirênica (sem caroço), goiaba, entre outros destaques. A vitivinicultura é desenvolvida sob características climáticas que a distingue das demais regiões tradicionalmente vitícolas, pois, através da irrigação, é possível programar colheitas para todas as semanas do ano e vinificações periódicas conforme a produção e a tancagem disponíveis (Figura 1). Uma parreira pode ser manejada e produzir até duas safras e meia ao ano, estabelecendo uma vantagem bastante singular quando comparada ao regime de safras vitivinícolas do resto do mundo (uma vez ao ano).

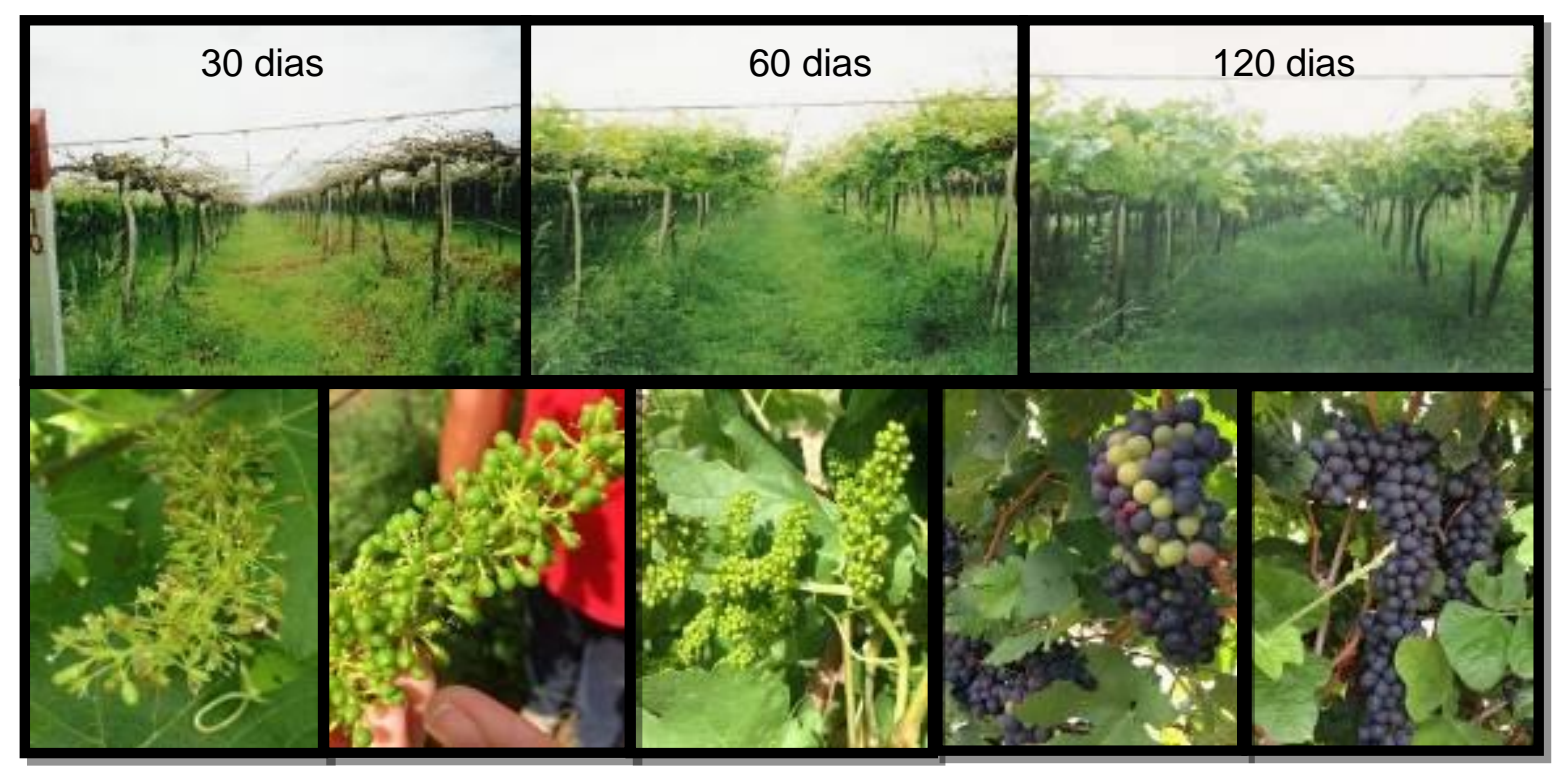

Figura 1: Processo de maturação da uva. Fonte: pesquisa de campo, 2014 Figure 1: Grape maturation process. Source: Field research, 2014

Considerada a segunda maior região produtora de vinhos finos do Brasil, o Vale do São Francisco representa 15\% do mercado nacional e chega a produzir aproximadamente 7 milhões de litros de vinho fino ao ano, conforme dados da VINHOVASF (2011), ficando atrás apenas das regiões viníferas do Rio Grande do Sul, com uma produção de aproximadamente 39 milhões de litros de vinho fino (IBRAVIN, 2015).

\section{Caracterização da área em estudo}

O local de estudo contempla os municípios de Lagoa Grande, Santa Maria da Boa Vista e Petrolina, localizados no semiárido de Pernambuco; e os municípios de Casa Nova e Sobradinho, no estado da Bahia. As vitivinícolas, objeto de estudo, estão localizadas às margens do rio São Francisco e a maioria delas estão na estrada da Uva e do Vinho, trecho pernambucano. Inicialmente, foram cinco fazendas produtoras de vinhos que realizam visitas monitoradas: Fazenda Planaltina - Vitivinícola Santa Maria, Fazenda Garibaldina - Vitivinícola Lagoa Grande, Adega Bianchetti Tedesco, localizadas no município de Lagoa Grande; Fazenda Milano - Vinícola Vale do São Francisco, em Santa Maria da Boa Vista e Vinícola TerraNova, em Casa Nova - BA. 
O acesso a essas vinícolas é feito pela Rota da Uva e do Vinho, com exceção da TerraNova que se localiza na Bahia. A estrada, de $72 \mathrm{Km}$ de extensão, parte da BR-428, em Lagoa Grande, até Santa Maria da Boa Vista. A rodovia possui iluminação e algumas placas indicativas das fazendas, entretanto, a sinalização rodoviária e turística é bastante precária, inexistindo placas informativas sobre velocidade máxima, quilometragem, ultrapassagem, por exemplo. Ao longo da estrada, estão instaladas 28 fazendas especializadas no plantio da uva, dessas, 8 estão focadas na fabricação de vinho. Na Figura 2 (mapa da região vinícola do Vale do São Francisco) podese obter uma melhor visualização da localização da região.

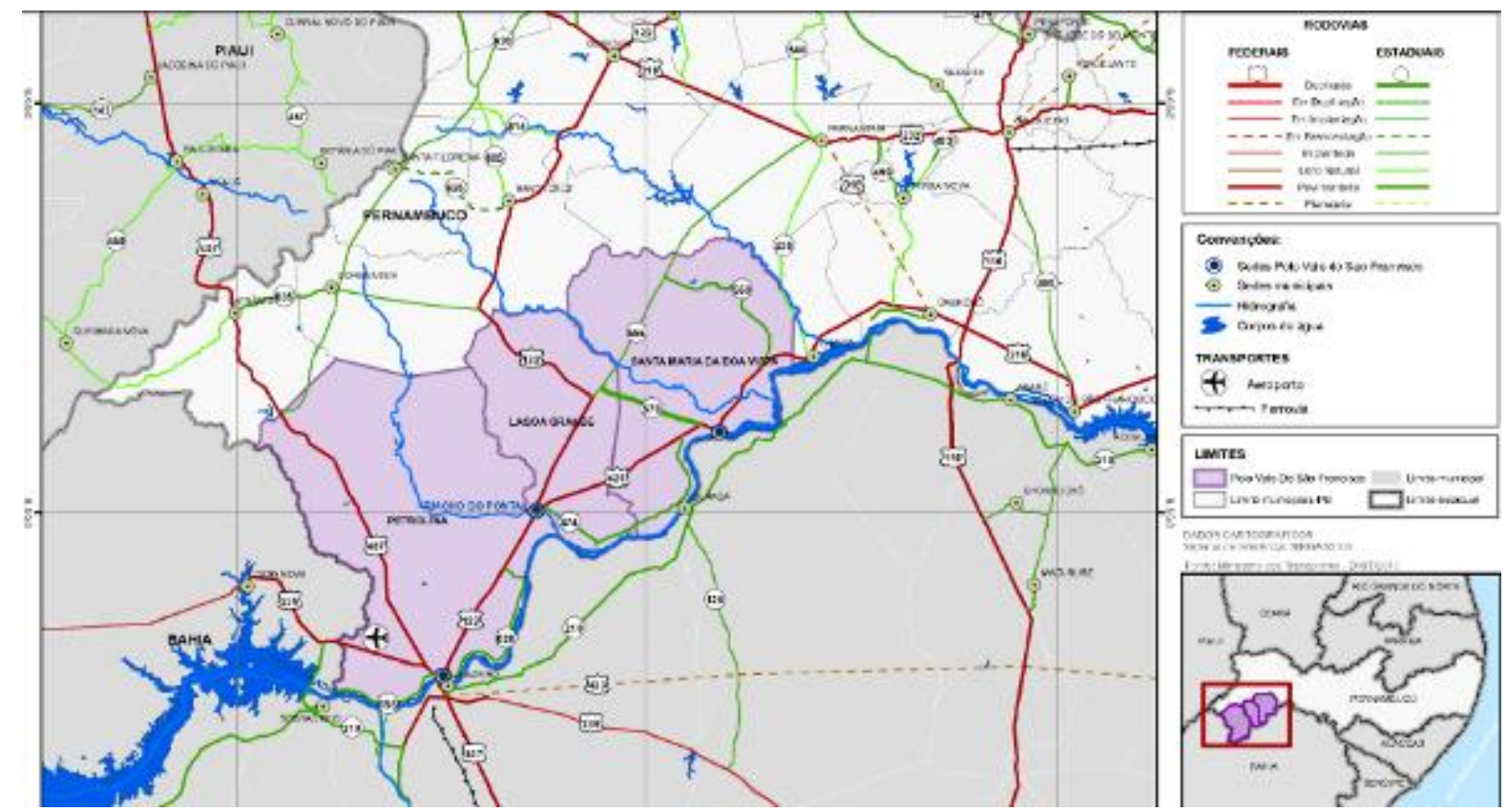

Figura 2: Mapa da região vinícola do Vale do São Francisco. Fonte: EMPETUR, 2012

Figure 2: Maps of wine region of San Francisco Valley. Source: EMPETUR, 2012

A Vitivinícola Vale do São Francisco, localizada em Santa Maria da Boa Vista, iniciou suas atividades em 1970 e é a pioneira na região. Foi fundada pelo italiano Franco Pérsico. A área total da fazenda é de 2.100 hectares, sendo 800 hectares para fruticultura irrigada (uva de vinho, uva de mesa e manga). Para plantação das uvas viníferas são utilizados 150 hectares. A vinícola produz os vinhos finos da marca Botticelli e o espumante Cristal do Vale, que é comercializado em todo o Brasil, principalmente no mercado nordestino, e exportado para a Dinamarca e Alemanha. Possui adequada infraestrutura para receber visitantes: uma agrovila, onde residem alguns funcionários, uma capela dedicada a Nossa Senhora da Conceição, ambulatório médico, escola para os filhos dos empregados, área de lazer (campo de futebol), refeitório e uma casa sede em estilo rústico, à beira do Rio São Francisco.

A vinícola também realiza experimentos para identificar o melhor sistema de condução da videira. Algumas castas estão no sistema de latada, outras de espaldeiras. A adubação e fertilização ocorrem pelo método de 
irrigação por gotejamento, o que permite maior economia e controle de água, como também controle da fertilização nos ciclos vegetativos correspondentes. O bombeamento é feito a partir das margens do rio São Francisco, utilizando equipamentos de sucção da água (Figura 3). As maiores vinícolas possuem aparelhos similares, no entanto, empresas de menor porte se utilizam desses equipamentos localizados na Vinícola Vale do São Francisco, demonstrando o caráter de associativismo entre diversos produtores.

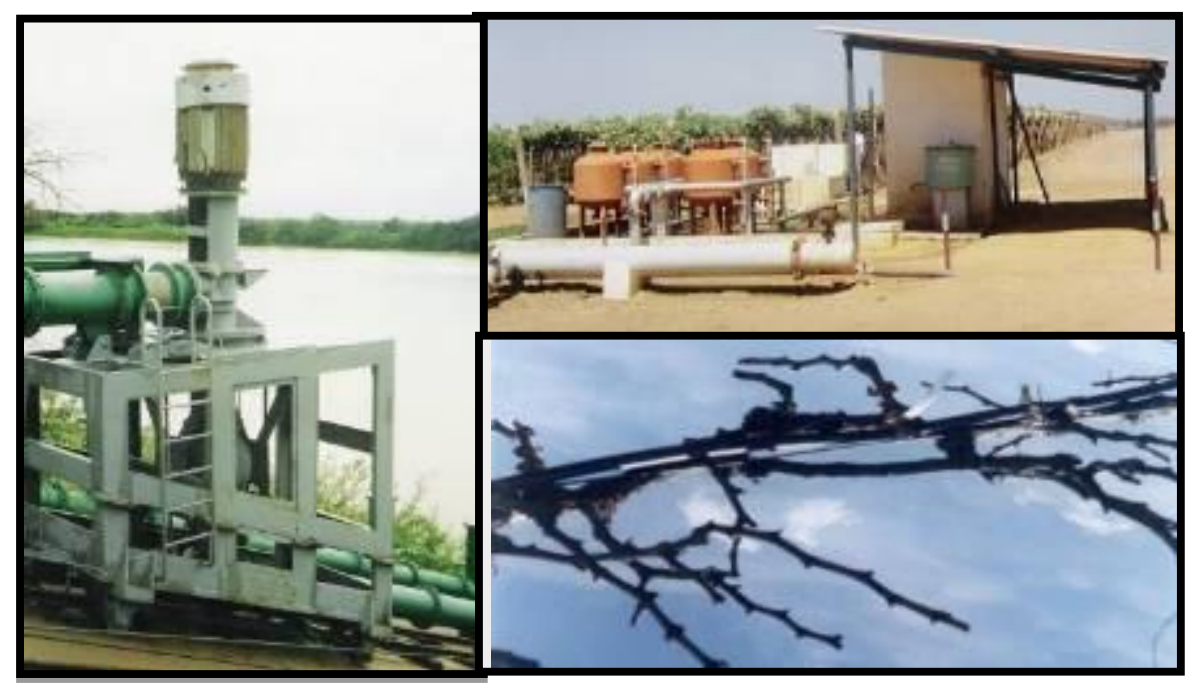

Figura 3: Sistema de fertiirrigação. Fonte: Pesquisa de campo, 2010 Figure 3: Irrigation system. Source: Field research, 2010

A Adega Bianchetti Tedesco está localizada no Km 20 da estrada da uva e do vinho, em uma área total de 200 hectares. De propriedade dos enólogos Izanete e Inaldo Tedesco, a vinícola iniciou suas atividades em 1998 a partir de um financiamento obtido junto ao Banco do Nordeste - BNB. A Adega Bianchetti Tedesco é procurada pelos visitantes pela qualidade dos vinhos produzidos e pela estrutura rústica e artesanal de produção, além dos vinhos orgânicos produzidos, tornando, assim, um atrativo diferenciado. Os principais vinhos produzidos pela Bianchetti têm como destinos os mercados da Região Metropolitana de Recife, Petrolina e os estados de São Paulo, Bahia e Minas Gerais, por exemplo. Em 2008, a Adega passou a produzir e comercializar vinhos finos orgânicos.

Os vinhos orgânicos são elaborados através de um processo natural, com uvas cultivadas seguindo as normas internacionais para agricultura orgânica, obedecendo critérios vinculados a certificação do Instituto Biodinâmico-IBD. Esta primeira iniciativa na região busca manter seu processo de acordo com o equilíbrio e a preservação do meio ambiente. Com efeito, segundo pesquisa sobre o comportamento de consumidores de vinhos orgânicos realizada por pesquisadores da Universidade de Stenden Holanda, Hoekstra et al. (2015, p. 284-285) afirmam que "organic prodution enhances the liveliness of the terroir that result in great terroir experience ${ }^{3 "}$, o que pressupõe grande relevância sobre a origem e produção de vinho para os consumidores e vitivinicultores. 
A Vitivinícola Lagoa Grande, de propriedade do empresário Jorge Garziera, natural de Garibaldi - RS, possui 200 hectares de plantação de uva destinadas à produção de vinho, finos e de mesa. Sua linha comercial foi operacionalizada em 2002, com a produção e venda do vinho tinto Shiraz e o espumante Moscatel tipo Asti. A Sede da Fazenda fica em um prédio de dois andares com 23 apartamentos, varanda panorâmica, onde se avista 0 parreiral e a área de produção (Figura 4). No interior do prédio, há um chafariz que jorra água avermelhada, alusiva a uma fonte de vinho. Possui ainda um restaurante, no piso superior. No térreo, funciona uma sala audiovisual, para que os visitantes tenham o primeiro contato a respeito da história da vitivinicultura no País e especialmente na região.

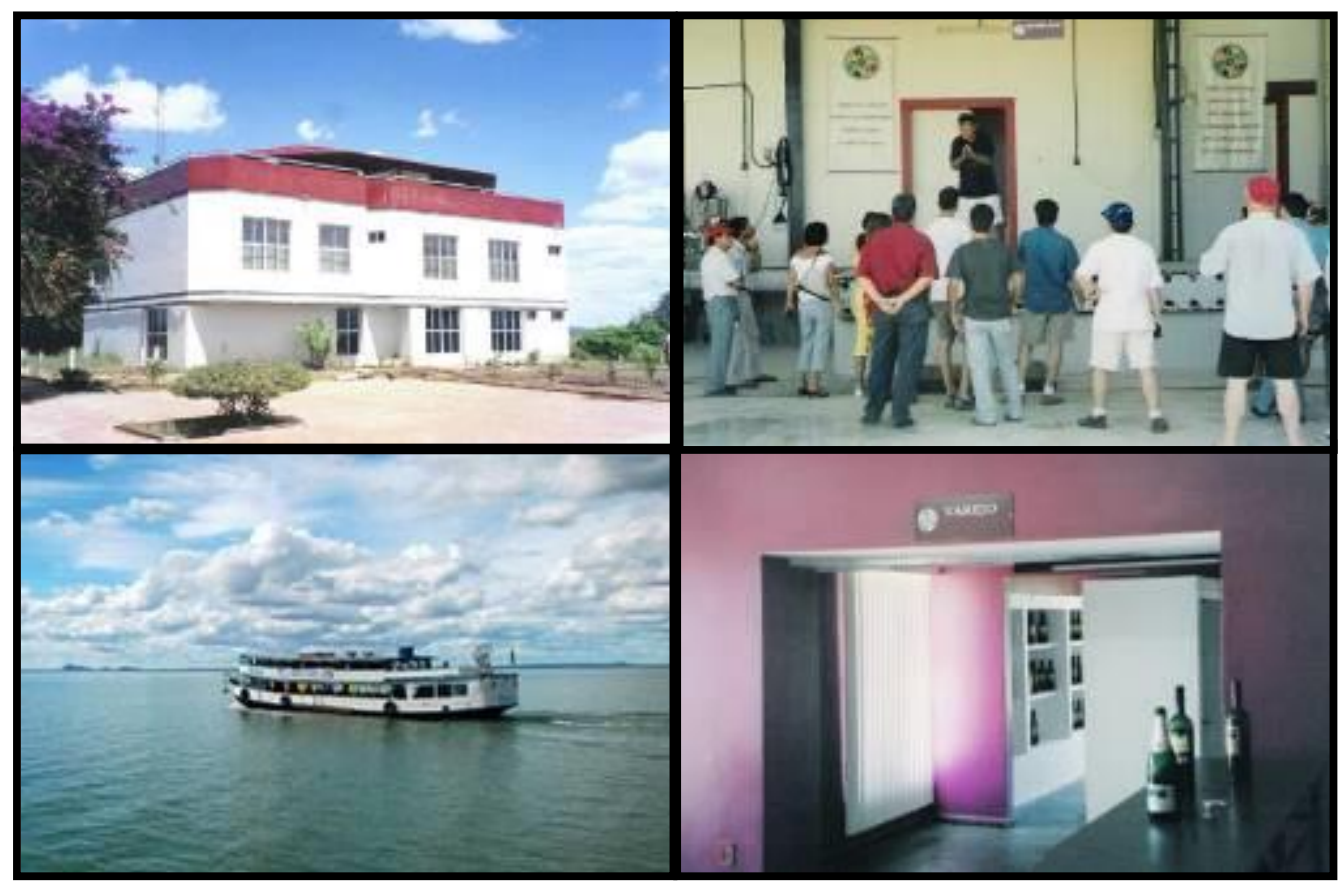

Figura 4: Enoturismo. Fonte: Pesquisa de campo, 2010-2014 Figure 4: Wine tourism. Source: Field research, 2010-2014

O passeio pela vinícola tem seu início na própria sede, na sala multimídia, com a apresentação de vídeo. $\mathrm{Em}$ seguida, com acompanhamento e explicações do enólogo, o grupo se desloca para a plantação, onde haverá informações sobre irrigação, poda, colheita e processo de vinificação. Na área de produção, os visitantes observam tal processo. Para a degustação, o grupo segue para a sede, onde são oferecidos, na cantina, pratos da gastronomia regional acompanhados dos vinhos produzidos. $\mathrm{Na}$ área de varejo, o turista pode comprar produtos vínicos como também artigos de produção mais artesanal, confeccionados na própria região.

A Vitivinícola Santa Maria, localizada a $8 \mathrm{Km}$ da BR-428, possui 350 hectares destinados a produção de uvas viníferas. A fazenda surgiu no início dos anos 80 com a compra da Companhia Italiana de bebidas Cinzano, fornecedora do vinho para a produção do vinagre da marca Minhoto de 
propriedade do empresário Raymundo da Fonte. A partir de então, a vitivinícola passou a cultivar uvas apropriadas para a produção de vinhos finos. A fazenda possui uma agrovila e alojamento para seus funcionários. Nesta, existe uma réplica da Igreja de Nossa Senhora do Carmo que havia na outra fazenda, hoje submersa pelo Lago de Itaparica no município de Floresta.

Nos últimos anos, a Vitivinícola Santa Maria passou por algumas modificações gerenciais e se associou a duas outras empresas, a Expand Store, importadora e distribuidora de vinhos no Brasil e a Dão Sul, empresa vinícola com sede em Portugal. Essas três empresas criaram a Empresa Vinibrasil, administrada pelo sócio português. São 200 hectares para a produção de vinhos. Em relação à infraestrutura na área de vinificação, a vinícola Santa Maria (Vinibrasil) possui duas cantinas, com grande capacidade para produção de vinhos finos, que vem produzindo um vinho de corte das castas Cabernet Sauvignon e Syrah, o Rio-Sol, já lançado no mercado em junho de 2004, além do lançamento do Paralelo 8, para exportação, ambos premiados nacional e internacionalmente. A vinícola ainda produz o Rio Sol envelhecido em barril de carvalho francês $(85 \%)$ e americano (15\%), também premiado.

Seguindo esses arranjos mercadológicos, a empresa Ouro Verde Ltda. adquiriu as instalações da antiga Vitivinícola Terra Nova, implantada ainda na década de 70 pelo japonês Mamoru Yamamoto e instalada no município de Casa Nova - BA. Deste empreendimento, participam a Vinícola Miolo Ltda. que se associou à empresa Lovara Vinhos Finos Ltda., fundando a Fazenda Ouro Verde, conforme notas técnicas da VALEXPORT e pesquisa realizada por Vital (2009).

Em 2003, inicia sua produção a Ducos Vinícola, localizada na estrada dos vermelhos, em Lagoa Grande - PE. De propriedade de empresários italianos e possuindo enólogo francês, a vinícola possui 124 hectares de área. Destes, 12 hectares são destinados aos vinhedos que produzem as viníferas Cabernet Sauvignon, Petit Verdot e Syrah - o vinho Chateau Duccos. Em 2013, lançou o Vale das Videiras, tinto suave, a partir da casta Bordeau. A vinícola investiu em tecnologia, adquirindo equipamentos para vinificação, engarrafamento e rotulagem. Inicialmente, foram investidos cerca de 5 milhões de Euros.

A Fazenda Passarin, como é conhecida na região, é uma das mais antigas em atividade. Sua implantação data de 1990, quando a produção estava voltada para a fruticultura em geral. No início dos anos 2000, os proprietários da fazenda investiram na produção e comercialização de vinhos finos e de mesa, a princípio, os vinhos era a granel, não sendo engarrafados na propriedade. Atualmente, a Vitivinícola Vale do Sol passou a comercializar os vinhos do vale e caves do sol.

A partir de 2008, duas outras vinícolas passam a oferecer a possibilidade de visitação: a Ouro Verde (grupo Miolo) e a Ducos, esta última ainda não opera o turismo de forma rotineira, apresentando apenas visitações esporádicas, por não oferecer infraestrutura suficientemente adequada para atendimento ao turista. Já a Ouro Verde, Garziera e Vinibrasil apresentam 
maior expressividade na oferta do enoturismo, possuindo satisfatória infraestrutura turística, com área de receptivo em torno de 250 a $400 \mathrm{~m}^{2}$, sendo dividido em adegas, área de produção e sala de degustação. A Ouro Verde possui parceria com uma empresa de receptivo e oferece passeio de catamarã pelo rio São Francisco, regado aos vinhos produzidos na vinícola. Já no caso da Garziera ainda apresenta sala de vídeo, memorial do vinho e restaurante panorâmico com vista para o parreiral e a produção (Figura 4). A seguir, de acordo com Quadro 1, pode-se observar as datas de instalação e associação destas empresas e seus respectivos produtos.

Quadro 1: Vinícolas do semiárido nordestino. Fonte: Adaptado de VITAL (2009).

Frame 1: semiarid northeastern Wineries. Source: Adapted from VITAL (2009).

\begin{tabular}{|c|c|c|c|c|}
\hline VINÍCOLA & MUNICÍPIO & $\begin{array}{c}\text { ANO DE } \\
\text { INSTALAÇÃO }\end{array}$ & $\begin{array}{l}\text { ANO DE } \\
\text { PRODUÇÃO } \\
\text { DE VINHO }\end{array}$ & $\begin{array}{l}\text { MARCA(S) } \\
\text { DO } \\
\text { PRODUTO }\end{array}$ \\
\hline Vale do São Francisco & $\begin{array}{l}\text { Santa Maria da Boa } \\
\text { Vista - PE }\end{array}$ & 1970 & 1986 & Botticelli \\
\hline $\begin{array}{l}\text { Adega Bianchetti } \\
\text { Tedesco }\end{array}$ & Lagoa Grande - PE & 2000 & 2001 & Bianchetti \\
\hline $\begin{array}{l}\text { Vitivinícola Lagoa } \\
\text { Grande }\end{array}$ & Lagoa Grande - PE & 1990 & 2001 & $\begin{array}{l}\text { Carrancas } \\
\text { Garziera }\end{array}$ \\
\hline $\begin{array}{l}\text { Vitivinícola Santa Maria } \\
\text { Vinibrasil }\end{array}$ & Lagoa Grande - PE & $\begin{array}{l}1987 \\
2004\end{array}$ & $\begin{array}{l}2004 \\
2004\end{array}$ & $\begin{array}{l}\text { Adega do } \\
\text { Vale } \\
\text { RioSol } \\
\text { Paralelo } 8 \\
\text { Rendeiras } \\
\text { Vinha Maria }\end{array}$ \\
\hline Ducos Vinícola & Lagoa Grande - PE & 2001 & 2003 & $\begin{array}{l}\text { Chateau } \\
\text { Ducos }\end{array}$ \\
\hline $\begin{array}{l}\text { Bella Fruta Ltda. } \\
\text { Vitivinícola Vale do Sol }\end{array}$ & Lagoa Grande - PE & $\begin{array}{l}1990 \\
2004\end{array}$ & $\begin{array}{l}2000 \\
2005\end{array}$ & $\begin{array}{l}\text { Vinhos do } \\
\text { Vale } \\
\text { Caves do Sol }\end{array}$ \\
\hline Ouro Verde Ltda. & Casa Nova - BA & 1985 & 2002 & $\begin{array}{l}\text { Terra Nova } \\
\text { Miolo }\end{array}$ \\
\hline
\end{tabular}

Os roteiros ofertados na região são comercializados pelas agências de viagens e/ou diretamente nas vinícolas com agendamentos prévios. Todos os roteiros seguem praticamente uma mesma estruturação em que é possível visualizar os parreirais e as diversas fases de crescimento da uva, conhecer o processo de produção e engarrafamento do vinho e por fim realizar a degustação, o que leva o turista inevitavelmente à compra de algum produto da vinícola. 


\section{Multifuncionalidade: produção de vinho, turismo e lazer}

O vinho é uma bebida bem antiga e, ao longo da história, esteve associado a ritos e passagens religiosas, como também a festividades profanas. Além disso, possui grande importância econômica. Para Roese (2008, p. 71-72), a simbologia vinculada ao vinho foi apropriada de maneira intensa pelo mercado de bebidas e atribui a sua imagem certa tradição: os enólogos e proprietários de vinícolas "associam a produção do vinho a um processo quase mágico" e assim, essa tradição resulta em produto bem singular, quase como uma obra de arte. Nesse sentido, o vinho produzido em uma vinícola possui características próprias. Essa particularidade gerou peculiaridades no crescimento econômico mundial de comércio de vinhos e o transformou em produto global. Na última década, o mercado internacional foi bem significativo, inclusive a nível de Brasil. E é nesse sentido que vinho se transforma, também, em produto de visitação turística, modificando a dinâmica espacial e social das localidades. Trata-se, portanto, de fenômeno recente, que envolve a mística associada à qualidade do vinho com o seu local de produção, cantina.

Durante a visitação às unidades produtivas, são oferecidas a degustação e a venda de produtos locais, também são incluídas visitas guiadas nas cantinas e degustação dos vinhos produzidos na localidade. $O$ itinerário é propositadamente estudado, onde podem ser visitados: museus, vinhedos, zonas produtivas. Além disso, as vinícolas foram lançadas como produto turístico, algumas, inclusive, oferecem alimentação, hospedagem e serviços de lazer e entretenimento. O que Locks e Tonini (2005, p.160) asseveram é a provisão de bens e serviços que atraem o turista e não está associado apenas às cantinas, e sim aos "negócios envolvidos com o vinho, o turismo e as indústrias associadas com a região vinícola. Isto inclui meios de hospedagem, guias, lojas de presentes, parques nacionais".

Roese (2008) alerta para o fato de que, na busca pelo incremento desse processo de vinificação e produção de vinhos com indicação de procedência, também surgem, oportunamente, mercados associados ao aumento da importância da bebida, por meio de venda de acessórios para degustação e conservação do vinho e, ainda, busca pelo conhecimento específico e necessário a uma degustação requintada, como os cursos de enologia, sommelier e harmonização de vinho, seja in loco (durante as visitas) ou nas grandes cidades, como forma de fortalecer a marca, além de surgimento cada vez maior de uma literatura mais especializada. Assim, Conclui Roese (2008, p.78), "o mercado do vinho (...) é um segmento com um dinamismo muito significativo e que está contribuindo para a dinamização de economias locais".

Em regiões tradicionalmente conhecidas por produção de vinho, como Bourdeaux - França, Valpolicella e Frascatti - Itália, D' Ouro - Portugal e o Vale dos Vinhedos, no sul do País, percebe-se forte investimento em infraestrutura turística como tentativa de incrementar e complementar a atividade econômica associada à vinificação. Ao longo do percurso na Serra Gaúcha, por exemplo, pode-se encontrar, além das vinícolas, diversos serviços atrelados à temática, como restaurantes, pousadas, queijarias, 
artesanato. Nessa perspectiva, as vinícolas estão localizadas junto a uma área de crescente potencial turístico e de lazer, reforçado pelo simbolismo atribuído ao vinho e à colonização, o que gera certa curiosidade em saber sobre o processo produtivo. No Vale do São Francisco, embora não se tenha tradição (nem cultural nem agrícola) na produção da bebida, há uma busca pelo aproveitamento do crescimento das vendas e consumo dos produtos locais e a novidade em implantar o turismo nas vinícolas do sertão nordestino.

Nesse sentido, os visitantes contribuem com o crescente mercado do vinho, ao se transformarem em consumidores e multiplicadores desse consumo. A cantina passa, então, a ser uma forma de divulgação e consolidação dos produtos, a visitação é também uma forma de marketing, de venda direta, de fortalecimento da marca e da imagem do vinho, da uva, do rótulo e da origem de indicação geográfica. Assim, a imagem dos produtos ofertados durante a visitação é percebida por meio de um significado intrínseco à região visitada. Segundo Roese (2008), constata-se que o vinho pode, de certa forma, não necessitar desse aparato turístico, do apelo às tradições para ser produzido, no entanto, para manter a marca e, consequentemente, as vendas, a vinícola precisará se inserir nessa nova dinâmica do meio rural.

Portanto, percebe-se a partir dessas análises uma relação de envolvimento e certo comprometimento dos agentes sociais vinculados à vinicultura e ao turismo. Embora trate de um tipo de atividade em que os elementos referentes ao processo de elaboração do vinho são o centro da experiência da viagem, faz-se necessário utilizar outros atrativos regionais como estratégias de vendas e de mercado para produtos locais, incrementando e contribuindo para aumentar a permanência do turista na localidade visitada.

A percepção de que o turismo pode ser uma ferramenta para contribuir com a geração emprego e renda na região estudada deve ser entendida, pelos setores relacionados à atividade, como uma forma de utilizar a localidade conscientemente, promovendo a sustentabilidade e gerando, dessa maneira, um bom relacionamento entre a comunidade, o governo e o empresariado. A importância de toda e qualquer atividade em uma economia depende de suas pré-condições naturais e econômicas, e ainda, das características intrínsecas do município, em função de alternativas ao papel reservado ao setor de serviços, lazer, nova residência e turismo em sua estratégia de desenvolvimento econômico.

Assim, os governantes locais se associaram para promover 0 desenvolvimento regional da localidade, implementando o programa Vale do São Francisco, que contempla ações e financiamentos para algumas atividades econômicas, inclusive 0 turismo. Esse programa realizou levantamento das características gerais e específicas das localidades envolvidas e, mais especificamente sobre o turismo. O objeto do projeto é a vinicultura aliada ao turismo, entretanto, cada município consorciado possui atrativos a explorar. O projeto contempla ainda ações voltadas para o meio ambiente, com o incentivo à pesca e ao repovoamento de espécie. Além 
disso, existem ações para reflorestamento das matas ciliares, coleta de resíduos sólidos e estudos sobre o assoreamento do rio São Francisco.

Para inserir a região no processo de promoção e iniciativas integradas para redução das desigualdades, os Governos de Pernambuco e da Bahia investiram mais de $R \$ 1$ milhão em ações voltadas para a prática do turismo sustentável e para a consolidação do polo vitícola. Parte deste total foram verbas federais, através do programa PROMOVER. Os recursos provenientes dos estados foram destinados à instalação de equipamentos turísticos e reforma e requalificação de monumentos históricos, como também investimentos em urbanização e sinalização, a fim de promover a valorização do patrimônio e, também, incrementar o volume de visitação, gerando emprego e renda à população. Os equipamentos, serviços turísticos e elementos do patrimônio são partes integrantes das ações governamentais estabelecidas pela RIDE4

Na esfera Federal, o Programa para o desenvolvimento do Turismo no Nordeste - PRODETUR-NE teve por objetivo, segundo Cruz (2000, p. 12), desenvolver os destinos, basicamente litorâneos, de infraestrutura de suporte para as atividades turísticas nessa região. Esse programa teve duas fases, na primeira houve melhorias e ações complementares de infraestrutura básica e serviços em geral, ressaltando que ocorreu apenas no litoral sul de Pernambuco. Em sua segunda fase, o PRODETUR-NE implementou ações no âmbito do Patrimônio Histórico, sistema de abastecimentos e obras de urbanização turística e ainda melhoramento do Centro de Convenções de Pernambuco e ampliação do Aeroporto Internacional dos Guararapes, em Recife. Vale salientar que essas obras continuaram contemplando apenas municípios litorâneos e capital do estado. Contudo, esse programa consolidou o estado como turismo de sol e praia em detrimento das potencialidades interioranas.

No âmbito do Governo Estadual, segundo dados da Agência Estadual de Planejamento e Pesquisa de Pernambuco - CONDEPE (2003, p.03), algumas ações foram implementadas por meio do Plano Plurianual 2004-2007 com o objetivo de aumentar a competitividade dos produtos e serviços, a partir da implantação de zonas turísticas. Esse programa está baseado na estruturação de roteiros turísticos com o objetivo de atrair maior número de turistas para a região. Para tanto, o Governo está investindo em ações para inserir o Festival do Vinho de Lagoa Grande no calendário de eventos e, ainda, implantar o projeto turístico Rota da Uva e do Vinho.

Nesse sentido, a região está se consolidando como polo de desenvolvimento, abrangendo arranjos industriais e também de serviços turísticos. Para a consolidação do Polo Vitícola, o Governo investiu em ações voltadas para vitivinicultura, visto que a produção de vinhos finos está em expansão. São investimentos da iniciativa privada e do setor público. Da contrapartida do Governo, está em implantação o Centro Tecnológico da Uva e do Vinho em Lagoa Grande, com o objetivo de auxiliar cooperativas na base de produção local, contribuindo para melhoria dos produtos cultivados na região (CONDEPE, 2003, p. 01). 
O Plano Territorial do Entorno da Estrada da Uva e do Vinho contempla ações na área de educação e capacitação profissional, alfabetizando jovens e adultos e formando agentes de desenvolvimento, como técnicos agrícolas para trabalhar junto aos assentamentos e pequenas unidades agrícolas. Além da iniciativa pública, os empresários do setor vitícola estão realizando diversas ações a fim de consolidar a qualidade dos vinhos do Vale do São Francisco nos mercados nacional e internacional. Uma das ações é estabelecer um selo de qualidade (Denominação de Origem Controlada), visando a demarcação das áreas das diferentes espécies de uvas cultivadas e criando indicações geográficas. Essa ação amplia as perspectivas de crescimento da vitivinicultura e reforça a manutenção de um espaço identitário, influenciando no desenvolvimento regional, já discutido anteriormente.

Outro programa para incentivar o crescimento da atividade vitícola é o Projeto Setorial Integrado para o vinho, uma parceria SEBRAE, VALEXPORT e Apex-Brasil (Agência de Promoção de Exportações do Brasil), que propõe a criação de um consórcio para exportar os vinhos com a marca do Vale, a fim de proporcionar aos pequenos produtores maiores condições de participação. Trata-se de uma perspectiva associativista, integrando os pequenos e grandes produtores no projeto. Essa iniciativa resultará numa boa divulgação da atividade vinícola, atraindo cada vez mais visitantes e contribuindo, dessa forma, para o fomento do enoturismo regional, aliado à gastronomia e aos atrativos do rio São Francisco.

Levando em consideração a análise de todos os fatos e ações implementadas na região do vale do São Francisco, foi realizado um quadro resumo (Quadro 2 - Ações desenvolvidas no polo vinícola), baseado nas esferas econômicas, sociais, culturais e de cidadania. Essas ações foram levantadas de acordo com a realidade vivenciada no pólo de vinicultura nordestino. Essas informações estão condensadas e foram obtidas por meio de entrevistas, pesquisas bibliográficas e observações.

Diante de todas as políticas e os programas planejados na região vinícola do nordeste, ainda se verifica pouca expressividade no que se refere à execução dessas ações, à tentativa de minimizar a pobreza e redução das desigualdades, principalmente sociais. Urge efetivamente de políticas públicas e ações coletivas (todos os atores sociais em conjunto) para promover mais ações voltadas para o desenvolvimento de capacidades dos indivíduos. 
Quadro 2: Ações desenvolvidas no pólo vinícola. Fonte: Pesquisa de campo, 2014 Frame 2: Actions taken in the wine pole. Source: Field research, 2014

\begin{tabular}{|l|l|l|}
\hline \multicolumn{1}{|c|}{ ÂMBITO } & \multicolumn{1}{|c}{ AÇÕES OBSERVADAS DURANTE A PESQUISA } \\
\hline Ações Políticas & $\begin{array}{l}\text { Direitos políticos associados à democracia: Programas e projetos } \\
\text { governamentais de participação social, inclusão nos perímetros } \\
\text { irrigados; comissões, planejamento participativo. Projeto de turismo }\end{array}$ \\
\hline Facilidades Econômicas & $\begin{array}{l}\text { Recursos econômicos com propósito de consumo, produção e } \\
\text { troca: melhoria de PIB, receita turística, incremento de postos de } \\
\text { trabalho no turismo, aumento na renda da população pela } \\
\text { participação na atividade turística }\end{array}$ \\
\hline Oportunidades Sociais & $\begin{array}{l}\text { Educação: Cursos de qualificação profissional; IFSertão } \\
\text { pernambucano; universidades, cursos técnicos, sistema S. todos } \\
\text { voltados para o incremento dos postos de trabalho em atividades } \\
\text { ligadas ao turismo } \\
\text { Infraestrutura: estradas, aeroporto, balneabilidade do rio, } \\
\text { saneamento básico, coleta de lixo. Acesso da população a serviços } \\
\text { públicos }\end{array}$ \\
\hline Segurança & $\begin{array}{l}\text { Aumento da rede segurança, combate às drogas, Programa } \\
\text { estadual "Pacto pela Vida". }\end{array}$
\end{tabular}

Segurança estadual "Pacto pela Vida".

\section{Considerações finais}

Dentro do panorama e diversas discussões e questionamentos que 0 novo rural tem apresentado, buscou-se trabalhar na visão contemporânea da multifuncionalidade e novas atividades que surgem dinamizando o meio rural. No Brasil, ações vêm sendo postas em prática em prol das responsabilidades que ao país lhe cabe, no tocante ao despertar para a necessidade de diversificação da sua economia, apostando nas potencialidades de que dispõe. E o turismo e outras atividades surgem no cenário econômico com uma certa força nos últimos 15 anos como uma alternativa encorajada inclusive pelo poder público.

Sabe-se que um dos pressupostos para a viabilidade $e$ sustentabilidade das atividades não agrícolas é a diversificação dos setores produtivos, pois a prática dessas atividades não deve ser vista como alternativa única capaz de salvar comunidades agrícolas em estagnação, ao contrário, deve-se perceber essas atividades justamente pela capacidade de interagir com outros setores, estimulando e dinamizando todas atividades produtivas. Busca-se que esta atividade possa gerar uma considerável melhoria na qualidade de vida das pessoas, ou seja, indutora de um processo legítimo de desenvolvimento. Entende-se que o estudo desta relação turismo e desenvolvimento - deva analisar para além dos indicadores econômicos, ou melhor, deve-se incluir os elementos qualitativos necessários à concretude de um processo de transformação social, vinculados a: saúde, 
educação, oportunidades sociais, inclusão, acessibilidade, oferta de lazer e cultura.

Conforme observado em pesquisa, a relação turismo e espaço provoca mudanças nas organizações espaciais visto que cria certas distorções na configuração dos espaços. A atividade se torna agente reorganizador dessas configurações ao criar núcleos de inclusão em atividades socioeconômicas, resultando na dinamização socioespacial. Assim, as análises realizadas nesse estudo podem contribuir para a compreensão do processo de expansão da utilização do turismo no espaço agrário da região do Vale do São Francisco, uma vez que tal atividade vem dinamizando a economia, reconfigurando o arranjo espacial local e atribuindo, dessa maneira, novas funcionalidades e novas formas de uso e apropriação do solo para fins turísticos.

Percebeu-se que o turismo foi (e vem sendo) estimulado pelos governos municipal, estadual e federal, por meio de ações e parcerias público-privadas e, dessa forma, encontra-se, atualmente, em fase de certa euforia no crescimento e, ao se associar à imagem da inovação, como no caso do agronegócio no semiárido nordestino, algumas de suas mais antigas tradições (como atrativos culturais, por exemplo), passam a também se tornar mais valorizado, oferecendo novas estratégias de diferenciação ao desenvolvimento regional. Ou seja, região de agricultura de subsistência, torna-se prospera devido à irrigação, passa-se a investir em grandes empresas para o agronegócio e, finalmente, aliado à vitivinicultura, agrega-se valor à localidade com o fluxo de turistas. Tudo se torna produto, mercadoria.

As atividades de lazer nas propriedades revelam importante elemento que vem a contribuir para a estratégia de negócio (comercialização, marketing e fortalecimento da marca) das empresas vitícolas, pois oferece oportunidades e ações complementares, reforçando a principal atividade agrícola, aliado aos fortes fatores da vitivinicultura e fidelização dos visitantes ao consumo do produto degustado. Revela-se, portanto, o fortalecimento da imagem do produtor e, consequentemente, da região. Considera-se que o vinho, a cultura do sertão nordestino, a alimentação regional e o turismo formam elementos centrais para a concretização de tais atividades. Assim, torna-se uma nova interpretação e utilização do mundo rural.

Portanto, no sentido de cooperação e solidariedade, busca-se aumentar as chances de que as atividades de lazer e turismo possam, de fato, ser capazes de diminuir as privações do nordestino e alavancar o desenvolvimento da escala humana. Percebe-se o quanto é imprescindível a ação do poder público como articulador e fomentador da condição dos cidadãos perante a atividade econômica vigente. 


\section{Referências}

ALMEIDA, J.A.; FROEHLICH, J.M.; RIEDL, M. (Orgs.). Turismo Rural e Desenvolvimento Sustentável. Campinas: Papirus: 2000.

BANKS, G.; OVERTON, J. Old World, New World, Third World? Reconceptualising the Worlds of Wine. Journal of wine research, v. 21, n. 1, pp. 57-75, set. 2010.

BARROS, N.C.C. Manual de Geografia do Turismo: meio ambiente, cultura e paisagens. Recife: Universitária, 2002.

BASTOS, F. O desenvolvimento e a natureza simbólica do progresso. Revista Economia política do desenvolvimento. V. 1. 2007. P. 09-31.

BONNAL, P; MALUF, R. S.. Políticas de desenvolvimento territorial e a multifuncionalidade da agricultura familiar no Brasil. In: Anais do Colóquio Internacional Sobre Desenvolvimento Territorial Sustentável. Florianópolis, 2007. p. 1-27.

CONDEPE. Instituto de Planejamento de Pernambuco. Governo nos municípios: Plano regional de inclusão social - São Francisco estratégico. Recife: CONDEPE/FIDEM, 2003.

CRUZ, R.C.A. Política de Turismo e Território. São Paulo: Contexto, 2000.

CARNEIRO, M.J. Política Pública e Agricultura Familiar: uma Leitura do Pronaf. Projeto Rurbano, 1999. 8p. disponível em: www.eco.unicamp.br/projetos/rurban14.html

CARNEIRO, M.J. Multifuncionalidade da agricultura e ruralidade: uma abordagem comparativa. In: MOREIRA, R.J; COSTA, L.F.C. Mundo rural e cultura. Rio de Janeiro, Mauad, 2002. P. 223-240.

CORRÊA, R. L. Espaço, um conceito chave da Geografia. In: CASTRO, I.E. et al. Geografia: conceitos e temas. 6 ed. Rio de Janeiro: Bertrand Brasil, 2003. p. $15-47$.

EMPETUR - Empresa de Turismo de Pernambuco. Região Vale do São Francisco. Mapa. Ambiens corporativo, 2012.

FALCADE, I. Vale dos Vinhedos: caracterização geográfica da região. Caxias do Sul: EDUCS, 1999.

FONSECA, M.A.P. Espaço, políticas de turismo e competitividade. Natal: EDUFRN, 2005.

FURTADO, C. Formação econômica do Brasil. 34 ed. São Paulo: Companhia das Letras, 2007. 351p.

GETZ, D.; BROWN, G. Critical success factors for wine tourism regions: a demand analysis. Tourism Management, v. 27, n. 1, p. 146-158, jan. 2006.

GRAZIANO DA SILVA, J. A nova dinâmica da agricultura brasileira. 2 ed. rev. Campinas: UNICAMP, 1998.

GRAZIANO DA SILVA, J. O novo rural brasileiro. Nova Economia, Belo Horizonte, v.7, n.1, 1997. p.43-81. 
GRAZIANO DA SILVA, J.; DEL GROSSI, M. Ocupações não-agrícolas e pluriatividade dos residentes rurais. Texto apresentado no Seminário Nacional de Desenvolvimento Rural Sustentável. Brasília, 23 a 25 de agosto de 2005.

HAESBAERT, R.. Dos múltiplos territórios a multiterritorialidade. Porto Alegre, 2004. Disponível em http://www.ufrgs.br/petgea/rtigo/rh.pdf. Acesso em nov 2014.

HOEKSTRA, I.; LASHLEY, C.; CAVAGNARO, E.. Generation Y's attitude towards organic wine. Revista Hospitalidade. São Paulo, v. XII, n. especial, p. 276-297, mai. 2015.

IBRAVIN. Instituto Brasileiro do Vinho. Dados estatísticos. 2015. disponível em http://www.ibravin.org.br, acesso em jan. 2016

KAGEYAMA, A.A. Desenvolvimento Rural: conceitos e aplicação ao caso brasileiro. Porto Alegre: Editora da UFRGS; Programa de Pós-Graduação em Desenvolvimento Rural, 2008.

LOCKS, E.B.; TONINI, H. Enoturismo: o vinho como produto turístico. Turismo em Análise. São Paulo: ECA-USP, v. 16. n. 2. 2005. p. 157-173.

RÍO RAMA, M.; ALVAREZ GARCÍA, J.; GÂNDARA, J.; VALDUGA, V.; RODRÍGUEZ GONZÁLEZ, P. Rute del vino Ribeiro Sacra (Galícia - España): Análises desde el punto de vista de la oferta enoturística. Turismo \& Sociedade, Curitiba, v. 7, n. 3, p. 554-575, jul. 2014

PEARCE, D.G. Geografia do Turismo: fluxos e regiões no mercado de viagens. São Paulo: Aleph, 2003. (Série Turismo).

RODRIGUES. A.B. Turismo e Geografia: reflexões teóricas e enfoques regionais. São Paulo: HUCITEC, 1996.

ROESE, M. O Mondovino de cabeça para baixo: as transformações no mercado internacional do vinho e o novo empresariado vinícola. Revista Sociologia Política. V. 16, n. 31. P. 71-83. Nov - 2008.

SCHLUTER, R. G. Gastronomia e Turismo. São Paulo: Aleph, 2003.

SCHNEIDER, S.; FIALHO, M.A.V. Atividades não-agrícolas e turismo rural no Rio Grande do Sul. In: ALMEIDA, J.A.; RIEDL, M. (orgs). Turismo Rural: ecologia, lazer e desenvolvimento. Bauru: EDUSC, 2000. p. 14-50.

SIMÕES, O. O enoturismo em Portugal: as rotas do vinho. Pasos, revista de turismo y património cultural, v. 6, n. 2, p. 269-279, 2008.

SPLENDOR, F. Vinhos: degustação e serviço, saúde, enoturismo. Caxias do Sul: EDUCS, 2003. (Coleção Hotelaria).

VINHOVASF. Instituto do Vinho do Vale do São Francisco. Histórico. Disponível em: http://www.vinhovasf.com.br, acesso em abril 2011.

VITAL. T.W. Vitivinicultura no Nordeste do Brasil: situação recente e perspectivas. Revista Econômica do Nordeste, vol. 40, n. 3, p. 499-524, 2009. 
WANDERLEY, M.N.B. Territorialidade e ruralidade no Nordeste: por um pacto social pelo desenvolvimento rural. In: Planejamento e Desenvolvimento dos Territórios Rurais: conceitos, controvérsias e experiências. Brasília: EMBRAPA, 2002.

\section{Notas:}

1 Para Mariot, excursão é a visita a vários lugares durante o percurso. Campbell afirma que para o excursionista o percurso é a principal atividade da viagem, realizando paradas durante o passeio (PEARCE, 2003, p.30-31).

2 "simultaneamente uma forma de comportamento do consumidor, uma estratégia de desenvolvimento dos atrativos das destinações e oportunidade de marketing para os vinicultores venderem seus produtos diretamente aos consumidores." Tradução dos autores.

3 "a produção orgânica reforça a vivacidade do terroir, o que resulta em uma experiência mais significativa". Tradução dos autores.

${ }^{4}$ RIDE - Região Integrada de Desenvolvimento. Abrange os municípios de Petrolina, Santa Maria da Boa Vista, Lagoa Grande e Orocó, em Pernambuco; Juazeiro, Casa Nova, Sobradinho e Curaçá, na Bahia.

Patrícia Lins de Arroxelas Galvão: Instituto Federal de Alagoas, Maceió, AL, Brasil.

E-mail: parroxelas@yahoo.com

Link para o currículo Lattes: http://lattes.cnpq.br/7675452061314676

Cleber Augusto Trindade Castro: Universidade Federal do Rio Grande do Norte, Natal, RN, Brasil.

E-mail: cleber.castro@hotmail.com

Link para o currículo Lattes: http://lattes.cnpq.br/0347315623106403

Priscilla Carla Leite Marques: Secretaria de Turismo do Recife, Recife, PE, Brasil.

E-mail: priscillaclm@gmail.com

Link para o currículo Lattes http://lattes.cnpq.br/7662075444582781

Data de submissão: 24 de agosto de 2016

Data de recebimento de correções: 13 de fevereiro de 2018

Data do aceite: 23 de fevereiro de 2018

Avaliado anonimamente 